\title{
The Influence of Entrepreneurship Education and its Contribution to Entrepreneurial Behavior of Students
}

\author{
Opy Triansyah, Kustoro Budiarta, Muhammad Fitri Rahmadana \\ Universitas Negeri Medan, Indonesia \\ opi.triansyah@gmail.com
}

\begin{tabular}{ll}
\hline Article History & Received : Feb $9^{\text {th }} 2021$ \\
& Revision : April $13^{\text {th }} 2021$ \\
& Publication : June $30^{\text {th }} 2021$ \\
\hline
\end{tabular}

\begin{abstract}
entrepreneurship is considered able to stimulate regional development and economic growth and can encourage the growth of innovation and supported by the development of education. However, with this statement, of course, each country or university has a different strategy in shaping a strategy to improve the quality of entrepreneurs born. This research was conducted in the environment of Medan State University with the population of Students of Medan State University, Sampling techniques using saturated sample method with a sample count of 126 people. The data obtained was analyzed using Structural Equation Modeling Techniques operated through the AMOS20 program. The results showed that there is a direct influence of entrepreneurial experience, Entrepreneurial Motivation and Organizational Culture on Entrepreneurial Behavior through Entrepreneurial Education
\end{abstract}

Keyword : Entrepreneurial Experience, Entrepreneurial Education, Entrepreneurial Behavior

\section{INTRODUCTION}

The progress of economic growth must be supported by the development of education, so that indirectly all parties participate in improving the quality of self, which the quality of self must be created with a quality education. The party that plays the most role in the field of education is the government, the responsibility is given fully to the minister of education and culture. one of the government's efforts in improving the quality of education is to develop curriculum and educational programs that directly impact human life. Entrepreneurial education is believed to have unchanging results changing in quantity and quality growth, however, schools and colleges offer entrepreneurial education with varying variations, despite much entrepreneurial education research conducted in business in schools. One of them is to form independent individuals by incorporating an entrepreneurial curriculum in vocational high schools and colleges.

Entrepreneurial development is intended to influence one's behavior in entrepreneurship in order to increase business success. Its also instrumental in balancing the economy that demands contributions from entrepreneurs, so that research on entrepreneurial behavior is growing, many variables can be used as a reference to see 
how much impact entrepreneurial behavior has on prospective entrepreneurs. The purpose of this study is to find out if there is a direct influence of experience Entrepreneurship, Entrepreneurial Motivation and Organizational Culture towards behavior Entrepreneurship through Entrepreneurship Education sees other factors that affect entrepreneurial behavior especially students who are already entrepreneurial who are basically already incorporated in an entrepreneurial organization. How their motivational and cultural experiences form an attitude that can be relied on in the world of entrepreneurship both outside the university and within the university, both during the course of graduation and after graduation. According to bps data, the open unemployment rate by region in August 2018 was $5.34 \%$ or recorded as many as seven million people from the labor force. The unemployment rate of 5.34 percent is still higher at 0.04 percent compared to the government's Work Plan target of $5.0 \%$ to 5.3 percent.The open unemployment rate is an indicator that can be used to measure the levelof employment offer not by themarket. Based on the above problems that have been designed, the research hypothesis can be formulated as follows: H1: There is a direct influence of Entrepreneurial Experience on Entrepreneurship Education H2: There is a direct influence of Entrepreneurial Motivation on Entrepreneurial Education H3: There is a direct influence of Organizational Culture on Entrepreneurship Education H4: There is a direct influence of Entrepreneurial Experience, Entrepreneurial Motivation and Organizational Culture on Entrepreneurial Behavior through Kew Education efforts.

\section{METHODS}

This type of research is quantitative research. Quantitative research method is research based on the philosophy of positivism, used to research on a particular population or sample. Sample determination techniques are generally done by census by taking all populasi, data collection using research instruments, quantitative / statistical data analysis with the aim to test the hypothesis that has been set (Sugiyono, 2009: 13). In the implementation of this research, researchers chose the location of Medan State University which is located at JL. William Iskandar Market V Medan City. The research time is in odd semester $2020 / 2021$. The population in this study was 150 people. Of these populations, 126 were sampled in this study. The sampling technique used is census. The data analysis used in this study is Structural Equation Modeling (SEM) by first testing the dimensions with confirmatory factor analysis. The SEM model will also be analyzed to obtain and evaluate the proposed model match. as follows: 


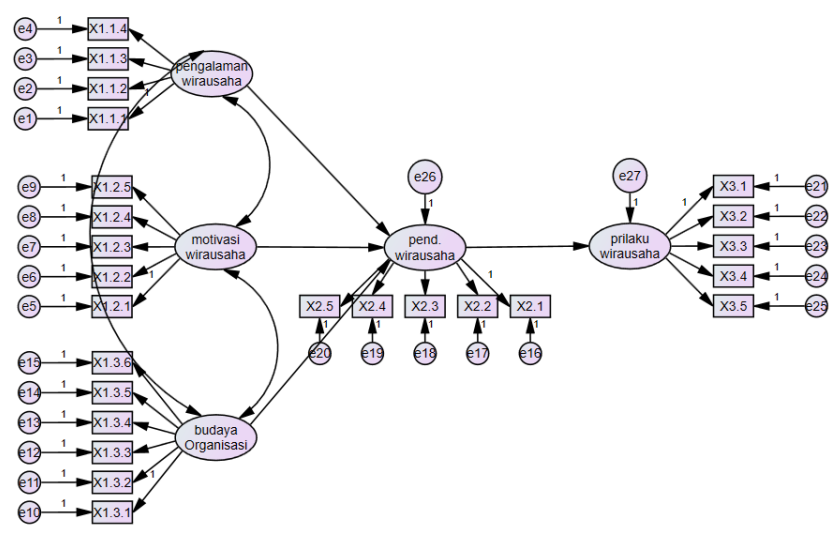

Endoge Variablen = Exogenous Variable + Endogenous Variable + Equation Error

$$
\begin{aligned}
& X_{2}=b_{21} X_{1}+e_{1} \\
& X_{3}=b_{31} X_{1}+b_{32} X_{2}+e_{2}
\end{aligned}
$$

in data processing, there are seven steps that must be done when using a complete SEM model consisting of Measurement Model and Structural Model. Aimed at confirming the dimensions developed on the Subah Factor.

\section{RESULTS AND DISCUSSION}

The test result of Hypothesis one states that the CR value obtained from the estimated influence of entrepreneurial experience on entrepreneurial education is 0.973 greater than the cr value of $>0.05$ so the hypothesis is accepted. Berartti can be said that the variable can have an effect. Thus this is in accordance with the results of research conducted by Sri wahyuni ( 2014) Andika Wahyudiono (2016) who concluded that entrepreneurial experience has a significant effect on corporate education this is in line with the theory put forward by Gurbuz \&Aykol (2008) confirms that education, experience and supply of entrepreneurship from an early age can increase one's potential to become an entrepreneur, in addition to the support of academic, social and business environment.thus can be formulated as the findings of this study is that "the more experienced a person is in entrepreneurship the higher the interest to study entrepreneurial education"

The test result of Hypothesis two states that the CR value obtained from the estimated influence of entrepreneurial motivation on education is -,601 is not greater than the $\mathrm{cr}$ value of $>0.05$ so the hypothesis is unacceptable. . Thus this is in accordance with the results of research conducted Josia (2014) in his research variable self-attitude and 
motivation does not affect entrepreneurial interests but in contrast to the research of bayu ilham (2020) entrepreneurial motivation affects entrepreneurial interests . from the results of differences in test results of each researchers seen there are differences in test results although the variable used one of the factors is the population of the data obtained where the population has the driving force or drive to behave. this is reinforced by Motivation is a driving force or drive of a person to behave certainly that can arise from within or outside the individual. Motivation is the encouragement both from others and from oneself to do a job consciously and passionately to achieve a certain target (Mulyadi, 2015). thus can be formulated as the findings of this study is that "the better the entrepreneurial motivation of a person in entrepreneurship, the higher the interest to study entrepreneurial education"

The test result of hypothesis three states that the CR value obtained from the estimated influence of educational motivation on education is 0.974 . Because the CR value $>0.05$ is acceptable. . This is in accordance with the results of research conducted by Bryan (2019) The results show that organizational culture and work behavior simultaneously have a positive and significant effect on employee performance. Partially the organizational culture has a positive and significant effect on employee performance, and work behavior has a positive and significant effect on employee performance. Thus, the findings of this study can be formulated as that the culture of an organization can improve performance in entrepreneurship or entrepreneurial behavior.

The test result of hypothesis four states that the CR value obtained from the estimated influence of entrepreneurial education on entrepreneurial behavior is 1,129 greater than the value of $\mathrm{CR}>0.05$ so the hypothesis is acceptable. The results of previous research Adelinia Citradewi (2016) with the results showed that personality, entrepreneurial education, and family environment simultaneously have a positive and significant effect on the entrepreneurial activities of students of Semarang State University. Then researcher Andhika Wahyudiono (2018) the results showed that entrepreneurial education, entrepreneurial experience, and the type of kelamain have a significant effect on entrepreneurial attitudes. Therefore, the finding of this study is that the better the experience, motivation and culture of the organization that he obtained earlier will increase interest in learning entrepreneurial education and will indirectly affect how an individual runs his business well.

\section{CONCLUSION}

Based on the data obtained from the results of the analysis conducted, the conclusions that can be advanced in this study are as follows:

1. CR value obtained from the estimated influence of entrepreneurial experience on entrepreneurial education is 0.973 greater than the value of $C R>0.05$ so the 
hypothesis is accepted. Means can be said that the variable can be influential.based on the results of the analysis above hypothesis 1 namely " there is a direct influence experience of Entrepreneurship on Entrepreneurial Education an" acceptable.

2. Cr value obtained from the estimated influence of entrepreneurial motivation on education is -,601 is not greater than the value of CR $>0.05$ so the hypothesis is unacceptable. It means that it can be said that the variable can not have an effect. based on the results of the analysis above hypothesis 1 namely " there is a direct influence of Entrepreneurial Motivation on Entrepreneurial Education an" is not acceptable or rejected.

3. The CR value obtained from the estimated influence of educational Organisai Culture on education is 0.974 . Because the CR value $>0.05$ is acceptable. Berartti can be said that the variable can have an effect. "there is a direct influence oft he Organization's Culture on Entrepreneurial Education and" is acceptable.

4. The $\mathrm{cr}$ value obtained from the estimated influence of entrepreneurial education on entrepreneurial behavior is 1,129 greater than the value of CR $>0.05$ so the hypothesis is acceptable. It means that it can be said that the variable can have an effect." there isa direct pen $g$ aruh pengalaman entrepreneurship, Entrepreneurial Motivation and Organizational Culture towards Prilaku Entrepreneurship through entrepreneurial education" is acceptable.

\section{ACKNOLEDGEDMENT}

The author expressed his gratitude to each chairman of the Entrepreneurial SME Organization at Medan State University, namely HIPMI, PKM and PMW Organizations who have helped in providing data to researchers in writing this article.we are also grateful to jecs journals that have provided opportunities to share knowledge.

\section{REFERENCES}

Ajzen, I. (2002), "Perceived behavioral control, self-efficacy, locus of control, and the theory of planned behavior", Journal of Applied Social Psychology, Vol. 32 No. 4, pp. 665-683.

Aldrich, H.E. and Cliff, J.E. (2003), "The pervasive effects of family on entrepreneurship: toward a family embeddedness perspective", Journal of Business Venturing, Vol. 18 No. 5, pp. 573-596.

Alvarez, J.L. (1996), "The role of business ideas in the promotion of unemployment: the case of

Arikunto, Suharsimi. (2010). Prosedur Penelitian Suatu Pendekatan Praktik.

BPS, (2017). https://www.bps.go.id/subject/6/tenaga-kerja.html\#subjekViewTab5.

Diakses pada 28 Februari 2019. 
Augusty, Ferdinand. (2006). Metode Penelitian Manajemen: Pedoman Penelitian Untuk skripsi. Tesis dan Disertai Ilmu Manajemen. Semarang: Universitas Diponogoro

Buchari Alma.(2013). Kewirausahaan. Bandung: Alfabeta

Bygrave DW. (1994). The Portable MBA in Entrepreneurship. John Wiley \& Son, Inc. New Jersey.

Chen, Y., \& He, Y. (2011). The impact of strong ties on entrepreneurial intention: an empirical study based on the mediating role of self-efficacy. Journal of Chinese Entrepreneurship, 3(2), 147158

Endang Mulyani. (2011). "Model Pendidikan Kewirausahaan Di Pendidikan Dasar Dan Menengah".vol4:4. Universitas Negeri Yogyakarta.

Fayolle, Et Al. (2006). Assesing The Impact Of Entrepreneurship Education Programmes: A New Methodology. Journal Of Europian Industrial Training, 30 (9), $701-720$.

Gerba, T. (2012). Impact Of Entrepreneurship Education On Entrepreneurial Interests Of Business And Engineering Students In Ethiopia. African Journal Of Economic And Management Studies, 3(2), 258-277.

Ghozali, Imam. (2006). Aplikasi Analisis Multivariate Dengan Program SPSS. Cetakan IV. Badan Penerbit Universitas Diponegoro Semarang.

Hendro. (2011). Dasar-Dasar Kewirausahaan. Jakarta: Penerbit Erlangga. Jakarta: Rineka Cipta.

Karimi, et al. (2016). The Impact Of Entrepreneurship Education: A Study Of Iranian Students' Entrepreneurial Interests And Opportunity Identification. Journal of Small Business Management, 54 (1), 187-209.

Kasmir. (2006). Kewirausahaan. Jakarta : PT Raja Grafindo Persada.

Keat, O.Y., Selvarajah, Chr. and Meyer, D. (2011), "Inclination towards entrepreneurship among

Koch, Lambert T. (2002). Theory and Practice of Entreprenerurship Education. Jerman: Universitu of Wuppertal.

Liñán, Fr. and Chen, Y. (2006), "Testing the Entrepreneurial Intention Model on a TwoCountry

Marques, et al. (2012) Entrepreneurship education: How psychological, demographic and behavioural factors predict the entrepreneurial interest. Education + Training, 54 $(8 / 9)$

Piperopoulos, P. (2012), "Could higher education programmes, culture and structure stile Postigo, S. and Tamborini, F. (2002), "Entrepreneurship education in Argentina: The case of San Andres University", International Entrepreneurship Education and Training Conference, IntEnt02, Kuala Lumpur, Malaysia. Processes, Vol. 50 No. 2, pp. 179211.

Reynolds, P., Storey, D. J., \& Westhead, P. (1994). Cross-National Comparisons of The Variation in New Firm Formation Rates. Regional Studies, 28(4) 
Riani, A. L., Sawitri, H. S. R. \& Rahmawati. (2012). Peran Eep Pada Perilaku Entrepreneurial Dan Kepuasan Kinerja Perajin Batik Surakarta, Karanganyar Dan Sragen. Jurnal Siasat Bisnis, 16 (2), 258-266.

Riani, Irianto dan Widodo. (2011). Analisis Faktor Penentu Niat Berwirausaha Mahasiswa Universitas Sebelas Maret. Rineka Cipta.

Sieger, P., Baldegger, R. and Fueglistaller, U. (2011). "Entrepreneurship Intentions and Activities of Students in Switzerland ", results from the GUESSS project, Swiss Institute for Small and Medium Enterprises at the University of St. Gallen. Germany: St Gallen.

Slameto. (2010). Belajar dan Faktor-faktor yang Mempengaruhinya. Jakarta: PT.

Solesvik, M., Westhead, P., Kolvereid, L. and Matlay, H. (2012), "Student intentions to become selfemployed:the Ukrainian context", Journal of Small Business and Enterprise Development,

Souitaris, V., Zerbinati, S., \& Al-Laham, A. (2006). Do entrepreneurship programmes raise entrepreneurial intention of science and engineering students? The effect of learning, inspiration and resources. Journal of Business Venturing, 22(4), 566-591. Sugiyono. (2013). Metode Penelitian Kuantitatif, Kualitatif dan R\&D. Bandung: Alfabeta. Suryana, (2014). Kewirausahaan: Kiat dan Proses Menuju Sukses. Jakarta: Salemba Empat.

Suryana. (2003). Kewirausahaan, Pedoman Praktis, Kiat dan Proses Menuju Sukses. Jakarta: Salemba Empat

Suryana. (2013). Kewirausahaan:kiat dan proses menuju sukses. Jakarta: Salemba Empat The entrepreneurial intentions of students?", Journal of Small Business and Enterprise Development, Vol. 19, No. 3, pp. 461-483. http://dx.doi.org/10.1108/14626001211250162 university students: An empirical study of Malaysian university students", International Journal of Business and Social Science, Vol. 2, No. 4. Vol. 19, No. 3, 